\title{
VESTIDO Y MUJERES EMANCIPADAS EN LA NARRATIVA DE EMILIA PARDO BAZÁN
}

\author{
DRESS AND EMANCIPATED WOMEN IN \\ THE NARRATIVE OF EMILIA PARDO BAZÁN
}

\section{Blanca Paula RODRÍGUEZ GARABATOS}

Universidad de Coruña

\begin{abstract}
Resumen: El tema de la Moda y el vestuario es para Emilia Pardo Bazán inagotable ya sea desde un punto de vista higiénico, moral, económico, social o puramente práctico. La autora gallega vive intensamente la moda y sus viajes al extranjero la mantienen en permanente contacto con la capital del mundo fashion y sus creaciones. Es por ello que sus novelas y cuentos están repletas de personajes construídos a través de la moda. Las mujeres independientes que pueblan sus cuentos y novelas desafían los códigos de conducta de la época vistiéndose de manera cómoda y práctica. La autora elabora la psicología de nuevos y modernos arquetipos literarios femeninos como Fe Neira, Miss Annie y Espina Porcel a partir de la vestimenta, el maquillaje y los complementos.
\end{abstract}

Palabras clave: literatura comparada, Emilia Pardo Bazán, Moda, narrativa, cartas inéditas.

Abstract: The theme of Fashion and costumes is for Emilia Pardo Bazán inexhaustible whether from a hygienic, moral, economic, social or purely practical point of view. The galician author lives intensely fashion and her trips abroad keep her in constant contact with the capital of the fashion world and her creations. That is why his novels and stories are full of characters built through fashion. The independent women who populate their stories and novels defy the codes of conduct of the time by dressing in a comfortable and practical way. The author elaborates the psychology of new and modern female literary archetypes such as Fe Neira, Miss Annie and Espina Porcel from clothing, makeup and accessories.

Key words: comparative literature, Emilia Pardo Bazán, Fashion, narrative, unpublished letters. 
Doña Emilia estaba al tanto de todas las novedades sobre el tema pero también tenía una teoría de la moda que es fruto, tanto de su interés, como de las oportunidades que sus viajes privados y su labor de cronista le proporcionaron para sumergirse en el universo fashion.

La autora constata la masculinización del vestuario femenino que irrumpe con fuerza en el mundo de la moda para permitir a las mujeres desarrollar sus inquietudes intelectuales y practicar nuevas actividades físicas y deportivas. Fe Neira emplea zapatos planos, Miss Annie usa bombachos para andar en bicicleta, Clara Ayamonte recurre a un abrigo-saco y un traje de auto para conducir su coche. Lina Mascareñas y Afra emplean trajes de baño para practicar natación. Manolita en La madre naturaleza se viste al estilo jockey para pasear. La adopción de esta vestimenta cómoda y funcional es consecuencia de las nuevas necesidades que impone la vida "moderna". La ropa servirá además para construir nuevos arquetipos literarios femeninos que coinciden con diversas caras de una poliédrica mujer nueva, la nueva Eva, que surge a principios del siglo XX.

\section{Feíta: la mujer intelectual}

Feíta es en Doña Milagros y en Memorias de un solterón la antítesis de su fashionista hermana Rosa. Si en Rosa Neira podemos apreciar la vacuidad de una mujer interesada sólo en emperejilarse para encontrar un buen marido, Fe es el icono de una femineidad cuyas inquietudes no coinciden con las de la mayoría de sus congéneres ${ }^{1}$. Con este personaje Pardo Bazán recoge las ansias de libertad y de conocimiento de muchas mujeres de su época. Ella misma, en una carta, escrita desde París en 1885 y dirigida a su comadre la señora Carmen Miranda de Pedrosa, expone y viste la ejecución de tales anhelos con unos pantalones femeninos de paño: «Como en Carnavales cierran la Biblioteca me fui a dar una vuelta por Italia, ya ves que soy valiente. He aquí adonde conducen las funestas teorías de la

\footnotetext{
${ }^{1}$ La moda práctica, 1911, nº 160. Señalaba sobre la feminidad de la época: «Es cierto que muchas mujeres hacen gala de su falta de feminismo, de que no saben lo que es sensibilidad ni sentimentalidad; pero no es menos cierto también que esas mujeres no son tan apreciadas como las que sólo se cuidan de hermanar su personalidad psicológica con sus encantos naturales: Por este motivo, en las mujeres médicos, abogados, arquitectos, etc., los hombres no encuentran tantos atractivos como en las que solo nos cuidamos de ser mujeres. Y esas, sólo esas, aceptarán los pantalones sin discutirlos. Si las primeras no experimentan la pequeña angustia que sentimos las demás y que nos hacen buscar al hombre como sostén y consuelo, tampoco poseen nuestros encantos, pues nosotras somos espíritus femeninos, nada más que femeninos. Y siendo así, ¿cuál será su vida? Porque lo principal, lo que nos ata a esto que han dado en llamar prosa antipática, y que no lo resulta, es nuestra condición, distinta en todo de la de los hombres». Citado en PASALODOS SALGADO, Mercedes, El traje como reflejo de lo femenino. Evolución y significado, Madrid 1898-1915, Madrid, UCM, 2000: 20 y 21. Ver también MAYORAL, Marina, “Tristana y Feíta Neira, dos versiones de la mujer independiente”, Galdós, centenario de Fortunata y Jacinta, J. Arellano (ed.) UCM, 1989: 337-344.
} 
emancipación femenina a que una se pasee por Milán y Padua como si una tuviese pantalones... de paño se entiende» ${ }^{2}$.

Feíta es un trasunto de Pardo Bazán ${ }^{3}$. La escritora, en sus Apuntes autobiográficos, relataba en estos términos su innata proclividad al estudio y la lectura: «iLibros, muchos libros, y todos a mi disposición, sin cristalera ni enrejado, pudiendo yo revolverlos, ponerlos, quitarlos, sin que se agotase nunca la fértil vena! ¿Dónde hay felicidad como la mía?» (PARDO BAZÁN 1999, II: 15, 16). Feíta expresa ante su padre idéntica pasión por los libros y esgrime esta inclinación como argumento irrebatible para que éste le permita estudiar:

Si Dios ha querido que el único varón de la casa sea un desaplicado y un bodoque... no nos vamos a reponer contra Dios. Es un dolor que esté usted derrochando dinero y paciencia con Froilán. Lo que gasta usted con él en matrículas y libros, ¿por qué no lo gasta conmigo? Yo tengo muy buena memoria. Con una vez que lea las lecciones, lo más dos, se me quedan. ¿Y qué piensa usted? entiendo lo que leo; me gusta muchísimo... Me trago el libro de texto, y no crea usted, también otros que no son de texto y... que... me los prestan. Sobrado me envió dos novelas de Víctor Hugo; Moragas me trajo obras de Camilo Flammarion...; hasta don Tomás Llanes me regaló unos novelones muy disparatados de ladrones y de moros. ¿Qué se había usted figurado? ¿Que soy una burra? Pues no hay tal. Me ha entrado un flus de leer... Leería toda la biblioteca del Puerto de un tirón. Hasta me zampo los libros de Argos divina, la Filotea, los escritos de Santa Teresa y los del Padre Faber... ${ }^{4}$ (PARDO BAZÁN 1999, III: 737)

Feíta no se resigna a los designios que la sociedad ha impuesto a las mujeres de su época:

Dios hizo a la mujer para la familia, para la maternidad, para la sumisión, para las labores propias de su sexo... ¡ ide su sexo! No lo olvides nunca, y que nadie tenga que recordártelo, o serás la criatura más antipática, más ridícula y más despreciable del mundo: un marimacho; ipuh! La mujer a zurcir medias... no se ha visto no se verá nunca que truequen los papeles a no ser en San Balandrán ${ }^{5}$ (PARDO BAZÁN 1999, III: 738).

Esta parrafada que le suelta su padre al principio de la novela es un recordatorio de esa aspiración constante que debe tener la mujer perfecta: ser ángel del hogar. Lo demás, según su progenitor, son locuras quijotescas. Pero Feíta no se desalienta y defiende la compatibilidad de ambas funciones: «Yo sé barrer y coser y cuidar de una casa, y sé criar un chiquillo, como crié a las gatas monas... pero me gusta estudiar, y estudiaré» ${ }^{6}$ (PARDO BAZÁN 1999, III: 739).

\footnotetext{
${ }^{2}$ Archivo RAG: MO 88/C. 4.6.

${ }^{3}$ Incluso en la relación entre Fé Neira y Mauro Pareja podemos encontrar un paralelismo con la que entabló Pardo Bazán con Juan Montalvo quien le llevaba casi diecinueve años. Además, según dice Isabel Burdiel, doña Emilia, al contrario que las lánguidas y románticas damiselas de su época, pretendía seducir desde su intelecto, su fortaleza y su alegría, cualidades que también adornan a Feíta. BURDIEL BUENO, Isabel, Emilia Pardo Bazán, Madrid, Taurus, 2019: 288.

${ }^{4}$ DE GABRIEL, Narciso, "Emilia Pardo Bazán, las mujeres y la educación. El Congreso pedagógico (1892) y la cátedra de Literatura (1916)", Historia y memoria de la educación, nº 8, 2018: 493. Pardo Bazán criticó enardecidamente la inferioridad intelectual congénita de todo el sexo femenino (Nuevo Teatro Crítico 22; 39-40) en el Congreso pedagógico de 1892.

${ }^{5}$ El género marimacho como tan despectivamente se describe en España se traduciría en lo que Virginia Woolf llama una mente andrógina que la autora describe como «resonante, porosa, que transmite emociones sin traba, es por naturaleza creativa, incandescente e indivisa». WOOLF, Virginia. Una habitación propia, Madrid, Alianza, 2012: 131.

${ }^{6}$ Esta actitud de Feíta es muy acorde con las ideas feministas de la época que recomendaban conciliar el desempeño de ciertos trabajos con las labores del hogar. Melchora Herrero de Vidal recomendaba a sus congéneres: «Habéis de ser compañeras del hombre, ángeles de su guarda, no tentadoras; habéis de ser amor, armonía, y para cumplir todo esto con el talento y la prudencia que corresponde a cada caso, una educación completa, física, intelectual y moral, y por consiguiente, una instrucción adecuada a dicho fin». HERRERO DE VIDAL, Melchora, Para las mujeres, reflexiones y consejos, Madrid, Imprenta de los hijos de M. G. Hernández, 1905: 50. PASALODOS SALGADO, Mercedes, Ibídem, p. 16.
} 
Si en Doña Milagros la personalidad de la chica queda bien definida, Memorias de un solterón destaca el valor de la inteligencia como elemento fundamental para enamorar a un hombre. El protagonista de la novela, Mauro Pareja, cae rendido ante los inexplicables, incluso para él, encantos de Feíta.

A ojos del recalcitrante solterón, Feíta se nos presenta como una muchacha en la que «no se descubre ni el menor asomo de coquetería, reserva o ternura femenil» (PARDO BAZÁN 1999, III: 826). Esta impresión queda corroborada líneas después, al describirnos el atavío y peinado de la protagonista:

Yo que me perezco por las mujeres ataviadas, peripuestas y pulcras, no me puedo acostumbrar a la manera de vestirse de esta chicuela indómita. Siempre anda metida en un talego o amarrada como un saco de garbanzos. Sus hermanas no la hacen caso, y ella no se cuida de sí propia, ni creo que recuerda que hay espejos en el mundo. Su pelo vive en perpetua insurrección: es el mambís más rebelde que conozco. Lo lleva corto porque no la da la gana de dejarlo crecer, ni de sujetarlo formando moño, ni de enterarse de para qué sirven la tenacilla y el alisador, y cada mechón va por su lado, unas veces crespos, otras lacios y mohínos, según la temperatura y la humedad (PARDO BAZÁN 1999, III: 827).

Feíta es desastrosa y le importa un bledo el qué dirán. Sus objetivos vitales están bien claros y el desaliño de su aspecto refleja que está centrada en lo que quiere y que no piensa atender a otras cuestiones que no sean de su interés, por mucho que se las impongan las conveniencias sociales. Su propio padre vive en permanente temor por el infausto destino que espera a esta hija díscola e inadaptada: «Feíta... con dolor lo declaro... es un monstruo, un fenómeno aflictivo y ridículo, y si Dios no lo remedia...» (PARDO BAZÁN 1999, III: 838).

Fe Neira es un icono de rebeldía y, desde luego pertenece al género marimacho ( PARDO BAZÁN 2004: 305) al que doña Emilia alude en Por Francia y por Alemania. El traje de visita que elige para visitar a don Mauro habla por sí solo:

Sólo entonces noté hasta qué punto se había exagerado en la muchacha su habitual aspecto de estudiantillo. Su pelo, más corto y revuelto que nunca, como si lo hubiese alborotado con los dedos, se escapaba del casquete o toca rusa, de piel; las líneas de su talle desaparecían bajo un chaquetón de paño, con bolsillos y solapas, prenda masculina; al cuello llevaba un pañuelo de seda arrollado y anudado al descuido; los guantes brillaban por su ausencia, y las botas eran grandes, duras, resquebrajadas, lo más opuesto a la coquetería y al arte de agradar, ¡lo que más desilusiona en una mujer! (PARDO BAZÁN 1999, III: 850).

Este calzado de la muchacha es también del gusto de la propia escritora quien, en una de sus cartas a su amiga Carmen Miranda de Pedrosa, alaba la comodidad del zapato plano frente a los peligros del zapato de tacón: «Veo que sigues cayéndote por todas partes, yo estoy algo curada de ese mal con el calzado inglés que ahora todo el mundo adopta: tacón plano y doble suela ancha. No hace muy bonito pero las ventajas son tan grandes, porque, en realidad esas caídas cuestan mucho y gracias cuando no te hiciste un daño más serio» ${ }^{7}$.

La comodidad es para Feíta fundamental y esto hace que prescinda del corsé, una costumbre que es objeto de censura por parte de la fashionista Rosa Neira. Fe no cede a las presiones (de ningún tipo) y ante las críticas de su hermana contesta airada: «Mejor, estoy así porque me da la gana; métete en

\footnotetext{
${ }^{7}$ Archivo RAG: MO 88/C. 1.15
} 
tus narices, presumidona» (PARDO BAZÁN 1999, III: 872). Si Feíta quiere estudiar, trepar por las estanterías, agacharse o encaramarse sobre pilas de libros no puede, de ningún modo, andar ceñida.

No obstante, su apariencia descuidada no significa que Fe Neira descuide su aseo. Lógicamente, en una muchacha inteligente y racional cabe esperar que los temas de la higiene sean considerados de importancia. Ella misma lo expresa así.:

Para andar aseada, lavo y plancho yo misma mi ropa, mis cuellos: ¿ve V. qué reluciente este de hoy? No lo llevará V. más blanco. Gasto mucha agua, remojo la cabeza dos veces por semana, y me paso el pelo con unos cristalitos de soda... a lo pobre, porque el shaampoing cuesta un sentido, y las yemas de huevo... son muy buenas para almorzarlas. También cuido las garras: ya he perdido la mala maña de comerme las uñas; las limo, las recorto, y así me ahorro guantes. Voy sin ellos. Ahora las tengo negras de polvo, y el pañuelo también, porque anduve revolviendo ahí arriba, y claro... Pero si V. me da un poco de agua y jabón... ¡verá qué manos de señorita! (PARDO BAZÁN 1999, III: 872, 873).

Esta, a ratos caricaturesca, muchacha, resulta no obstante enternecedora en la rectitud y tenacidad de sus aspiraciones. Mauro Pareja, el solterón, acabará cautivado por estas cualidades pero no sin oponer resistencia.

Pareja, apodado el Abad, tiene, necesariamente, que resistirse a sucumbir ante Feíta ya que su propia apariencia es impecable. Viste con pulcritud y elegancia, aseado pero sin excesos en su acicalamiento. Es un hombre chic, un dandy sin estridencias, que abomina de las osadías del traje del gobernador Luis Mejía o de los perendengues de legitimidad de Ramón Sobrado. Así expresa, él mismo, las razones del cuidado que dedica a su vestimenta:

He formado costumbre de vestir con esmero y según los decretos de la moda; mas no por eso se crea que soy de los que andan cazando la última forma de solapa, o se hacen frac colorado si ven en un periódico que lo usan los gomosos de Londres. Así y todo, mi indumentaria suele llamar la atención en Marineda, y se charló bastante de unos botines blancos míos. Lo atribuyo a que en las personas de amplias proporciones y que se ven de lejos, es más aparente cualquier novedad. Mis botines blancos tenían las dimensiones de una servilleta. No crean, señores, que me acicalo por afeminación. Es que practico (sin fe, pero con fervor) el culto de mi propia persona, y creo que esta persona, para mí archiestimable, merece no andar envuelta en talegos o en prendas, ¿Voy a vestirme como un cesante? Mil veces no. Me atrae todo lo que es confort, bien estar, pulcritud, decoro. Como que de estas condiciones externas pende y se deriva, en muchos casos, la paz del espíritu y la armonía del carácter ${ }^{8}$ (PARDO BAZÁN 1999, III: 781, 782).

Las tribulaciones de Mauro no dejan de ser bastante cómicas. Cuando empieza a enamorarse de Feíta, rechaza de plano tales sentimientos. En este repudio inicial subyace una actitud frívola ya que la negación de sus inclinaciones se basa, únicamente, en la apariencia de la chica: «A mi parecer, ni se me importaba un bledo del marimacho, ni al marimacho se le daba de mí un ardite. ¿Yo querer a semejante mascarón; a una chica que gasta calzado de hombre y lleva el pelo hecho un bardal? Si eso es el sexo femenino, ¡malhaya por siempre jamás amén» (PARDO BAZÁN 1999, III: 864, 865).

Paulatinamente, Pareja irá aflojando sus estrechas miras y empezará a reflexionar sobre las bondades de su amada comparándola con otras muchachas de la sociedad provinciana que le rodea. El

\footnotetext{
${ }^{8}$ DÍAZ MARCOS, Ana María, La edad de seda. Representaciones de la moda en la literatura española (1728-1926), Universidad de Cádiz, Cádiz, 2006: 183 según esta autora, el concepto de chic tiene que ver con lo singular (distinguirse) y con la autenticidad (el acuerdo entre lo que se es y lo que se muestra). Como vemos en sus propias declaraciones, en Mauro Pareja confluyen ambos aspectos y, en mi opinión, precisamente la autenticidad de Feíta es la cualidad que va a prevalecer en el proceso de enamoramiento de Mauro.
} 
desprecio por la indumentaria de Feíta, que empezó siendo para Mauro un problema insalvable, comienza a ser contemplado ahora como una virtud estimable:

Sobre el fondo burgués de la vida marinedina, destacábase con relieve singular el tipo de la muchacha que pensaba en libros cuando las demás pensaban en adornos; que salía sin más compañía que su dignidad, cuando las demás, hasta para bajar a comprar tres cuartos de hilo, necesitaban rodrigón o dueña; que ganaba dinero con su honrado trabajo, cuando las otras sólo añadían al presupuesto de la familia una boca comilona y un cuerpo que pide vestimenta; que no se turbaba al hablar a solas con un hombre, mientras las restantes no podían acogernos sino con bandera de combate desplegada... En suma, todo lo que al principio me pareció en Feíta reprobable y hasta risible y cómico, dio en figurárseme alto y sublime, merecedor de admiración y aplauso (PARDO BAZÁN 1999, III: 888).

El embeleso del solterón va a llegar a un punto de no retorno cuando, finalmente, se vea a sí mismo en la tesitura de dudar si es digno del amor de una mujer tan apreciable:

Y por qué no había de agradar este a mujer tan excéntrica, que probablemente tenía un ideal opuesto al de las demás señoritas marinedinas? ¿Qué importa una blusa, qué una gorra, qué una camisa sin planchar, a quien como Feíta desdeña formulismos y busca directamente la inteligencia y el carácter? (...)-todo añadido a su juventud y a su hermosura varonil, que sólo necesitaba algo de aliño para brillar-, eran razones más que suficientes para que Feíta pudiese ablandarse y compartir un sentimiento siempre halagüeño para la mujer (PARDO BAZÁN 1999, III: 893).

El nombre que Emilia Pardo Bazán ha elegido para la protagonista posee grandes dosis de humor e ironía ya que el sustantivo/nominativo Fe alude a la creencia inquebrantable de la joven en sus cualidades intelectuales mientras que el diminutivo Feíta, refleja su escaso atractivo físico. Fe Neira logra lo que todas sus hermanas desean: un matrimonio ventajoso. No solo se casa con un hombre rico sino que consigue lo que ella misma desea: una unión igual «en condición y derecho» (PARDO BAZÁN 1999, III: 925) para ambos contrayentes ${ }^{9}$. Fe alcanzará todo esto sin pretenderlo y sin recurrir a ninguno de los mecanismos de seducción de las muchachas casaderas. Desde luego, en este caso, para asombro de todos, la suerte de la fea...

\section{La chica Gibson: Miss Annie}

La chica Gibson representa la emancipación sartorial de la mujer estadounidense. Fue el primer stándar de belleza norteamericana reconocido globalmente y divulgado a un público de masas a través de la pintura la ilustración y la fotografía ${ }^{10}$. El arquetipo respondía al de una mujer activa y de espíritu libre cuya forma de vestir y gustos sencillos ayudarían a consolidar el estilo americano.

\footnotetext{
${ }^{9}$ DORCA, Toni, "Tres heroínas ante el matrimonio, Marisalada, Tristana y Feíta”, Lectora, heroína, autora: (la mujer en la literatura española del siglo XIX). III Coloquio (Barcelona 23-25 octubre 2002), 2005: 92 subraya la victoria de la rebeldía de Feíta al alcanzar este tipo de compromiso en igualdad. En esta idea insiste GUTIERREZ ALVAREZ, Ruth, "La batalla ideológica entre la carne y el espíritu. Una aproximación a los personajes femeninos de las últimas novelas de Emilia Pardo Bazán”, La tribuna. Cadernos de estudos da Casa Museo Emilia Pardo Bazán, nº 12, 2017: 32.

${ }^{10}$ EXPÓSITO GARCÍA, Mercedes, De la garçonne a la pin-up. Mujeres y hombres en el siglo XX, Madrid, Cátedra, 2016: 78 y 79. FUKAI, A., SUOH, T., IWAGAMI, M., KOGA, R., Y NII, R., MODA: Una historia desde el siglo XVIII al siglo XX. La colección del Instituto de la indumentaria de Kyoto, China, Taschen, Bibliotheca Universalis, 2006: 133. FOGG, Marnie, Moda, toda la Historia, Barcelona, Blume, 2014: 190. Este nuevo prototipo femenino fue creado por Charles Dana Gibson, artista, ilustrador y crítico social en una serie de ilustraciones entre 1890 y 1910 . El arquetipo fue reflejado en obras de novelistas como Edith Wharton y en las pinturas de Singer Sargent.
} 
La chica Gibson personificaba la belleza y la independencia y además, parecía capaz de sentirse realizada $^{11}$. Su físico era el de una mujer delgada y atlética no exenta de atractivo $^{12}$.

En La sirena negra (1908), Emilia Pardo Bazán nos ofrece un fiel retrato de esta chica moderna y liberada a través de Miss Annie, una joven y esbelta institutriz anglosajona:

Jamás me he dado cuenta de este carácter étnico, la blancura de la piel inglesa, como ahora. Es un blanco que será desesperante para un pintor: un blanco tintado imperceptiblemente de rosa té, un blanco virginal, «carne de doncella»... La misma blancura a lo Van Dyck se nota en la pierna larga, esbelta, derecha; en el brazo duro, nada corto; en el pie de mármol (PARDO BAZÁN 2000, V: 500) ${ }^{13}$.

Esta diligente niñera inglesa se nos aparece como una mujer desenvuelta y segura de sí misma, prototipo de la mujer trabajadora, distante pero a la vez tierna con su pupilo al que cariñosamente llama baby: «Baby, estáis sofocado, no os paréis. Vais sucio; permitid que os limpie la cara un poco [...] Hip, Baby, go» (PARDO BAZÁN 2000, V: 496, 500).

Firme en su objetivo de mantenerse en forma. Miss Annie desarrolla actividades al aire libre como andar en bicicleta, jugar al tenis, bañarse en el mar o caminar. El senderismo es una de sus aficiones más señaladas:

Annie se dedicó, entre otros deportes, al de sorprendernos a Rafael y a mí. No habiéndole yo fijado por qué parte de la campiña debía excursionar, con maravilloso olfato adivinaba la dirección de mis paseos, y se nos aparecía cuando menos lo pensábamos, vestida corto de franelatennis, gorra con insignias de algún club británico, palo de alpinista, y el pie cautivo, sin malicia aparente, en botitos recios y planos. Su figura moderna, atrevida, exótica, componía sobre el fondo de los pinos ancestrales, o al lado del caduco dolmen con barba de musgo (PARDO BAZÁN 2000, V: 496).

En este párrafo Pardo Bazán aprovecha para describir algunos de los elementos de la indumentaria deportiva que se incorporan al vestuario femenino gracias a las nuevas chicas Gibson. Miss Annie emplea traje corto para sus actividades de senderismo y sobre todo, zapatos con tacón bajo e incluso, en su caso, botas atadas por delante ${ }^{14}$. La joven trabajadora viste faldas cortas y una gorra de hule, prendas prácticas que no le impidan el desempeño de sus funciones: «La franela blanca de su traje masculino, corto de brazo y pierna, es menos dulce de color que su nuca, descubierta, porque la gorra de hule recoge el pelo, no tanto que unos abuelos locos no diableen cerca del arranque de las espaldas» (PARDO BAZÁN 2000, V: 500).

La Miss es el prototipo de una mujer nueva que toma poco a poco la bastilla de los espacios abiertos y camina sola, nada en el mar y practica otros deportes.

\footnotetext{
${ }^{11}$ EXPÓSITO GARCÍA, Mercedes, Ibídem, pp.76 y 77 señala que los atributos psicológicos de esta nueva mujer liberada de los dogmas de la autoridad fueron establecidos por la feminista Dora Black, esposa de Bertrand Russel en el prefacio de su obra The right to be happy.

${ }^{12}$ FOGG, Marnie, Ibídem, pp. 190 y 191 El prototipo físico estaba inspirado en la propia esposa de Gibson, Irene Langhorne, alta y de estrecha cintura, en la modelo Evelyn Nesbit y en la actriz Camille Clifford, esta última, ganadora de un concurso de una revista patrocinado por el ilustrador para encontrar la encarnación de la mujer ideal.

13 DÍAZ PADRÓN, Matías, "Religión y devoción de Van Dyck en el coleccionismo español del siglo XVII", Anales de Historia del Arte, n' 20, 2010: 129 y 136, ha subrayado la hermosura y la carnalidad de los personajes de la pintura de Van Dyck y, en particular, destaca la exquisita belleza de la Virgen con Jesús Niño de El Escorial y el descarnado realismo de los cuerpos macizos de los santos de este pintor.

${ }^{14}$ FOGG, Marnie, Ibídem, p. 191.
} 
La inagotable actividad física de la institutriz aparece reflejada en otros episodios de la novela. Mientras se baña junto a Rafaelín, Pardo Bazán aprovecha para ofrecernos un retrato de la liberación femenina que, no obstante, no está exento de una gran carga de erotismo a ojos de los hombres:

¿Qué es lo que pasa? Annie ha hecho un movimiento, se ha quitado su gorra de hule, el único recato de su atavío de bañista; el pelo rubio, mojado, se esparce y la rodea de una aureola de serpezuelas de cobre... ¿Sabe que la miro? ¡De cierto! Y, con paladas suaves, casi negligentes, vuelve hacia la orilla, toma al niño otra vez de la mano -imperiosa, pues el chico se resiste a salir y juega en el agua- y de pronto se detiene, sin soltar a Rafaelín (PARDO BAZÁN 2000, V: 501).

El pelo suelto es una metáfora de esta libertad moral ${ }^{15}$ de la que goza Miss Annie pero además se configura como recurso narrativo que excita el deseo del protagonista, el señor Montenegro, a quien hierve la sangre en las venas cuando la contempla, a continuación, en la misma escena de este modo: «Ella permanece descubierta y en pie frente a mis ojos, tal vez los únicos que la contemplan. ¿Para qué pide la capa?... La franela se pega a sus formas como el lienzo húmedo de los escultores a la estatua. Detallo el armonioso y contenido desarrollo de su hermosura» (PARDO BAZÁN 2000, V: 501).

El texto reitera además la despreocupación de Annie en cuanto a guardar el debido decoro en su vestimenta de baño. Piernas y brazos podían quedar desnudos, pero había que evitar los escotes y también que el tejido se ajustara y se pegara al cuerpo por efecto del agua ${ }^{16}$. La institutriz, deliberadamente, se exhibe ante su empleador con intenciones nada inocentes. Además, prescindir de la capa de baño, un accesorio que era fundamental al salir del agua para evitar resfriados ${ }^{17}$, indica una personalidad temeraria.

Annie es seductora porque es indiferente a su propia belleza y no la exhibe sino que la revela inconscientemente. No obstante, esta nueva mujer, no está exenta de ciertas coqueterías femeniles y muestra en su pie marmóreo unas «uñas [...] limadas cuidadosamente, y abrillantadas, sin duda, con polvos de coral, que reproducen en el atento observador la imagen, sensual y delicada, de las menudas conchas traídas por la ola, envueltas en perlas verdosas, resbalantes» (PARDO BAZÁN 2000, V: 500). La metáfora no puede ser más evocadora. Miss Annie tampoco descuida su higiene e incluso, va más allá del mero aseo y se perfuma: «Olía bien — sin duda usufructúa los perfumes de Rafaelín—» (PARDO BAZÁN 2000, V: 531)

La institutriz es una joven emancipada que se atreve a utilizar la bicicleta, un vehículo que representa la libertad de adentrarse sola en carreteras y caminos polvorientos, aunque esto provoque críticas y murmuraciones insidiosas:

El artefacto deportivo había venido de Vigo, la población europeizada más próxima a Portodor; y nos sucedía encontrar en las carreteras a la joven, seductoramente masculinizada por los bombachos de paño café y leche, la media escocesa y la gorrilla de tela blanca; sofoquinada por la rápida carrera, alborotadas, las guedejas color de cerveza blonda. Ante mi movimiento retráctil, pues yo no quería ir con ella, la miss sonreía

\footnotetext{
${ }^{15}$ MAGLI, Patrizia, Pitturare il volto. Il Trucco, l’Arte, la Moda, Venezia, Marsilio Editori, 2013: 52.

${ }^{16}$ PASALODOS SALGADO, Mercedes, Ibídem, pp. 334 y 335. La comparación de la Miss con la estatuaria clásica tampoco es casual si tenemos en cuenta que a comienzos del siglo XX (1908) se puso de moda el traje de baño llamado "túnica griega".

${ }^{17}$ Ibídem, p. 346.
} 
maliciosamente, me lanzaba los dos rayos de zafir doblete de sus pupilas y continuaba pedaleando... (PARDO BAZÁN 2000, V: 507).

Para practicar ciclismo, la inglesa utiliza una nueva prenda, los bombachos, un vestuario holgado $^{18}$, inspirado en los diseños de Oriente y que facilita la libertad de movimientos de las piernas que requiere este medio de transporte ${ }^{19}$.

No obstante, como ya hemos visto en su pedicura, Miss Annie no renuncia a ciertas dosis de aderezo y, cuando lo hace, su belleza es deslumbrante. Durante un almuerzo se presenta «de piqué verde claro, con una rosa lacre en el corpiño» (PARDO BAZÁN 2000, V: 515) y cuando viste traje de visita se ve muy favorecida a pesar de su modestia aparente:

La inglesa venía muy guapa, es justo reconocerlo; su pelo de luz, sencilla y hábilmente recogido, y su traje de linón gris, de corte original, exageraban su aire pudibundo y prerrafaelista; era una deslumbradora girl de cromo, de esas en cuya cara la rosa se disuelve en leche y el carmín se afina con transparencias de cristal (PARDO BAZÁN 2000, V: 531).

Muy interesante es la descripción de este vestido ya que evoca un estilo artístico de reminiscencias antiguas muy apreciado por los pintores prerrafaelitas. Esta indumentaria, normalmente, carecía de un corsé que la ciñese al cuerpo, estaba confeccionada para que cayese en pliegues sin planchar y se ceñía al talle con un cinturón ${ }^{20}$.

La hermosura de la Miss, es imposible de disimular. Vestida de sport, con excéntricos vestidos artísticos o con toilettes más refinadas, la institutriz es arrebatadora. Su vigor físico adquirido con la práctica deportiva se demuestra al final de la novela cuando, ante el abuso de su jefe, Gaspar Montenegro y después de un evidente coqueteo recíproco, la joven proporciona una respuesta inesperada a su empleador: «Avanzó sobre mí, y su vigorosa palma de jugadora de tennis y ciclista, huesuda bajo la morbidez, cayó sobre mi mejilla, respondiendo al claqueo de la bofetada un dolor vivo, un escozor violento, un desquicie de dentadura» (PARDO BAZÁN 2000, V: 532). Annie flirtea, deja ver las bondades de su físico, no se recata, es una mujer emancipada y finalmente una Pandora portadora de una caja de sorpresas no siempre agradables ${ }^{21}$.

${ }^{18}$ CORONA VERDÚ, Rafael, “La emancipación femenina a través del denuedo velocípedo”, Femeris, vol. 2, n 2, 2017: 130.

${ }^{19}$ Creados por Amelia Bloomer eran pantalones de estilo turco holgados y recogidos en el tobillo con un volante negro de encaje que se llevaban debajo de una falda hasta la pantorrillase combinaban con camisa blanca, corbata, corsé y sombrero de flores. FOGG, Marnie, Ibídem, pp. 192 y 193. EXPÓSITO GARCÍA, Mercedes, Ibídem, p. 77. El uso de bombachos o pantalones fue objeto de mofa y crítica entre los contemporáneos de Pardo Bazán e incluso, la generación posterior. La escritora madame Delarue Mardrus (1874-1945) citada por Carmen de Burgos expresa esta tajante opinión sobre el uso de pantalones: «Vestida con pantalones como los hombres la mujer no es más que un ser menudo, lastimoso y risible». DE BURGOS SEGUÍ, Carmen, El arte de ser mujer, Pedro Gómez Carrizo, editor, España, Biblok editores, 2018 : 109.

${ }^{20}$ FOGG, Marnie, Ibídem, pp. 186 y 187.

21 TABOADA NOYA, Ruth, La violencia en los cuentos de Emilia Pardo Bazán, Santiago de Compostela, Facultad de Filología, USC, 2016: 49 interpreta este bofetón como una manifestación del despecho de Annie ante la indiferencia de don Gaspar que prefiere un compromiso con la más dócil Trini. En mi opinión es más bien una respuesta airada de una mujer liberada ante la falta de escrúpulos de varones como Montenegro, que se aprovechan de su superioridad social. 
Vestido y mujeres emancipadas en la narrativa de Emilia Pardo Bazán

\section{El Arte de ser la nueva mujer}

Parafraseando a Carmen de Burgos, son muchas las mujeres de la narrativa pardobazaniana que se construyen a sí mismas oscilando entre la necesidad de ser hermosas y las legítimas aspiraciones de hacer gala de su capacidad e inteligencia o de sus aptitudes para el deporte.

No es Fe Neira la única muchacha de las novelas de doña Emilia con inclinaciones eruditas. Otras protagonistas diseñadas por la autora también comparten tales inquietudes en lugar de las que solían preocupar a las hembras más fashionistas. Ser una mujer rompedora no será fácil en una sociedad en la que cualquier intento por escapar a los roles tradicionales va a ser criticado severamente. Veamos como ejemplo las rabiosas palabras en contra de la emancipación femenina que escupe el enfermo protagonista del relato Feminista:

En los hogares reinaba la anarquía, porque, perdido el principio de autoridad, la mujer ya no sabe ser esposa, ni el hombre ejerce sus prerrogativas de marido y padre. Las ideas modernas disolvían, y la aristocracia, por su parte, contribuía al escándalo. Hasta que se zurciesen muchos calcetines no cabía salvación (PARDO BAZÁN 2018: 111, 112).

Leocadia, en El cisne de Vilamorta es una mujer independiente, es maestra y, no obstante la humildad de su posición social, se esfuerza en el desempeño de su oficio y trata de superarse a sí misma:

\footnotetext{
Poseía la media instrucción de las maestras, rudimentaria, pero bastante para infundir gustos exóticos en Vilamorta, verbigracia, el de las letras, en sus más accesibles formas -novela y verso-. Consagró a la lectura los ocios de su vida monótona y honesta. Leyó con fe, con entusiasmo, sin crítica alguna: leyó creyendo y admitiéndolo todo, unimismándose con las heroínas, oyendo resonar en su corazón los suspiros del vate, los cantos del trovador y los lamentos del bardo. Fue la lectura su vicio secreto, su misteriosa felicidad. Cuando rogaba a sus amigas de Orense que le renovasen la suscripción en la librería, hacían ellas chacota y ponían a Leocadia el apodo de literata. ¡Literata ella! ¡Ojalá! ¡Si pudiese dar cuerpo a lo que sentía, al mundo fantástico que dentro llevaba! Imposible: jamás alcanzaría su caletre, por mucho que lo estrujase, a producir ni una triste seguidilla. Almacenada se quedaba tanta poesía y tanta sensibilidad allá en los senos y circunvoluciones del cerebro, como el calor solar en la hulla. Lo que salía al exterior era prosa neta: gobierno de casa, economía, guisados (PARDO BAZÁN 1999, I: 658, 659).
}

Leocadia es una mujer leída, culta y admirada por sus congéneres dado que su educación supera, con mucho, a la que demuestran el resto de sus vecinas y conocidas. Su tragedia radica en que este caudal extra de conocimiento no le sirve absolutamente para destacar en nada. Carece de "una habitación propia", no hay para ella un nicho o un foro en el que hacer brillar sus conocimientos. El ámbito público, como ya hemos visto, estaba vetado a las mujeres y las féminas cultivadas, como Leocadia o como la propia Pardo Bazán, tenían muy complicado hacer valer sus ambiciones intelectuales ${ }^{22}$.

Las encorsetadas señoritas españolas no estaban habituadas al estudio o los trabajos intelectuales. En La prueba, las hijas del Subsecretario Barrientos, vecinas de Salustio Menéndez, son un ejemplo de la fatuidad de la mujer española decimonónica ${ }^{23}$ :

\footnotetext{
${ }^{22}$ PAREDES NÚÑEZ, Juan, "El feminismo de Emilia Pardo Bazán”, Cuadernos de estudios gallegos, Tomo XL, fascículo 105. CSIC, 1992: 307.

${ }^{23}$ Ibídem, p. 309.
} 
Las señoritas del primero eran prueba viviente de que andaba acertado mi amigo al insistir en la necesidad de crear una mujer nueva, distinta del tipo general mesocrático. ¿Quién podría sufrir la vida común con semejantes maniquíes? Pasábanse todo el día de Dios en la ventana, ya entre cristales, ya con el cuerpo fuera. Cuando no estaban así, en postura de loritos, martirizaban el piano, revolvían figurines, charlaban de modas, leían revistas de salones para husmear las bodas y los equipos de la gente encopetada, criticaban a sus amigas, fisgoneaban quién entraba y salía en casa de los vecinos, se miraban al espejo o daban vueltas a sus sombrerillos y trajes. A falta de otro género de doctrinas y conocimientos, su madre les inculcaba ideas de nimia corrección social, explicándoles día y noche lo que era bien visto y mal visto, lo que podían hacer y lo que no podían hacer unas señoritas (PARDO BAZÁN 1999, III: 235).

En la misma novela, en clara oposición con esta categoría de mujeres huecas, a las que el protagonista califica de maniquíes descerebradas: «De la cabecita de esas cuatro pollas no se saca para hacer un frito de sesos» (PARDO BAZÁN 1999, III: 235); encontramos a la mujer extranjera. Luis Portal, amigo del protagonista, manifiesta su extrañeza por el hecho de descubrir a una muchacha leyendo en el tranvía. Esta rareza encuentra su explicación en el dato de que la chica es anglosajona, tal vez estadounidense o inglesa:

Dos o tres tardes noté que en la misma Puerta del Sol entraba una señorita de aspecto extranjero. Chico, desde el primer día me llamó la atención. ¡Iba tan decidida y tan sencilla y tan seria! Por el camino sacaba un libro y leía. Miré de reojo... debía de ser una edición de Shakespeare, porque distinguí una lámina de Romeo subiendo por el balcón de Julieta. (PARDO BAZÁN 1999, III: 206).

La misteriosa lectora es Mó, y es calificada por Luis, su enamorado, como: «"La mujer del porvenir", hembra superior al nivel general de su sexo, libre de preocupaciones enfermizas; varonil en el mejor sentido de la palabra, que es el que implica fuerza, entendimiento y resolución» (PARDO BAZÁN 1999, III: 267, 268).

Como Feíta pero aún más radicalmente, Mó Baldwin es una mujer que nada tiene ver con el arquetipo español y que es producto de la ilustración extranjera ${ }^{24}$. Esta educación también se refleja en La Quimera en el personaje de Clara Ayamonte a quien su padrino le procura en su infancia una governess inglesa, Miss Butter, quien le inculca el adagio mens sana in corpore sano y el amor por la lectura (PARDO BAZÁN 1991: 212).

Tener una institutriz o una criada inglesa es síntoma de adquisición, no sólo de hábitos de vida adecuados, sino también de buen gusto. En Dulce dueño, Lina Mascareñas elogia el chic de su nueva doncella:

Maggie, la doncella, no inglesa, sino escocesa, pero vezada y amaestrada en Londres, nada menos que en la casa de Lady Mounteagle, lo más superferolítico. Esta mujer, a juzgar por las señales, es una perla. Chata, cuarentona, de pelo castaño con reflejo cobrizo, de tez rojiza, de ojos incoloros, posee en el servir un chic especial. Se siente uno persona elevada, al disponer de tal servidora. Indirectamente, con un gesto, rectifica mis faltas de buen gusto, cuanto desdice de mi posición y de mi estado (PARDO BAZÁN 1989: 222).

\footnotetext{
${ }^{24}$ MAYORAL, Marina, "Emilia Pardo Bazán ante la condición femenina”, Estudios sobre la obra de Emilia Pardo Bazán. Actas de las jornadas conmemorativas de los 150 años de su nacimiento, A Coruña, Fundación Pedro Barrié de la Maza, 2003: 111 califica a Mó de posibilidad fallida.
} 
En la misma novela la protagonista, influida sin duda por su sirvienta, se inicia en la práctica de la «natación recobrando el humor juvenil de moverme, de hacer ejercicio, de bañarme en el mar, sin necesidad probablemente» (PARDO BAZÁN 1989: 225).

La admiración de Lina, por el higienismo british la lleva incluso a destacar el cuidado del aseo corporal de los británicos, cualidad que ya veíamos en Miss Annie: «-Me atrae su aseo — declaro-. No debe de oler una multitud inglesa como una multitud de otros países. El vaho humano, en esa nación...» (PARDO BAZÁN 1989: 237). Durante la novela, Lina experimenta cambios en su mentalidad que muestran a una incipiente mujer nueva ${ }^{25}$. Esta modernidad naciente en Lina se revela en sus nuevas aficiones como bañarse, navegar en barca con su pretendiente «bien engaritados en nuestros gruesos abrigos de paño, caladas las gorrillas de visera, de cuarterones, que habíamos comprado iguales, tomamos asiento en la barca» (PARDO BAZÁN 1989: 255) o, como ella misma dice, en su «continuo afán de conocer los aspectos de la montaña, de recorrerla, de afrontar sus caprichos aterradores» (PARDO BAZÁN 1989: 252). Naturalmente, su vestuario va a incorporar piezas insospechadas para poder desarrollar sus nuevos hobbies deportivos: «Maggie, silenciosa, dispone mi baño y coloca en orden la ropa que he de ponerme para bajar a almorzar, mis atavíos de turista, mis faldas cortas de sarga o franela tennis, mis blusas "camisero" de picante airecillo masculino, mi calzado a lo yankee...» (PARDO BAZÁN 1989: 250). Lástima que estos brotes de modernidad $^{26}$ se marchiten al final de la novela sustituídos por el repentino arrebato místico de Lina que la conduce a su definitivo encierro ${ }^{27}$. Este giro en el comportamiento de Lina se verá reflejado de nuevo por un cambio en su indumentaria ${ }^{28}$.

El estilo de vida inglés es, asimismo, alabado con entusiasmo en La Quimera por la duquesa de Flandes quien destaca la importancia que los habitantes de la pérfida Albión otorgan a la práctica de «un poco de ejercicio; ¡aquí la gente vive sentada...!... - Bicicleta por lo menos» (PARDO BAZÁN 1991: 293). El ciclismo es, como ya hemos visto en el caso de Miss Annie, una deporte implantado ya entre muchas mujeres emancipadas. En Un viaje de novios, las cubanas Amézagas también emprenden actividades físicas sumamente novedosas importadas de Inglaterra, en su caso, el patinaje: «Yo voy a que Worth me haga dos o tres trajecitos... sencillos [...] Uno de patinar... ¡me muero por el Skating» (PARDO BAZÁN 2003: 215). Sus habilidades en la práctica de este deporte van a generar la admiración del mismísimo rey quien con su «figura juvenil [...], con su rostro pálido de frío, su cuerpo

${ }^{25}$ GUTIERREZ ALVAREZ, Ruth, Ibídem, p. 32.

${ }^{26}$ POZO GARCÍA, Alba, "Quiero ser santa: misticismo y decadencia en Dulce dueño de Emilia Pardo Bazán", La tinta en la clepsidra. Fuentes, historia y tradición en la literatura hispánica, Barcelona, Boadas, Chávez y García Vicens (eds), 2012: 261.

${ }^{27}$ EXPÓSITO GARCÍA, Mercedes, Ibídem, p. 70 recoge la idea de Simone de Beauvoir quien cree que en las figuras de la mujer narcisista, enamorada y mística hay un desdoblamiento del yo. La Lina Mascareñas de Dulce dueño pasa del narcisismo (amor por ella misma) al misticismo (amor a Dios). En ambos estados Lina huye de sí misma para refugiarse en ideales del yo forjados por su propia mente. El estado narcisista se ven traducido en el relato de Pardo Bazán a través de la indumentaria de la protagonista que la define como una mujer fashionista y sportwoman.

28 «Salí de Madrid dos semanas después, al anochecer, con una maleta vieja por todo equipaje. Llevaba puesto lo más sencillo que encontré en mi guardarropa: traje sastre, de sarga, abrigo de paño color café con leche. Ni guantes, ni sombrero. Un velillo resguardaba mi cabeza y mi faz, ya deshinchada, en que sólo la mella del diente recordaba el suceso. Mi peinado era todo recogimiento y modestia» (PARDO BAZÁN 1989: 273). 
esbelto, sus modales sueltos y elegantes, y su sonrisa entre picaresca y cortés, al inclinarse para felicitar a la ágil patinadora» (PARDO BAZÁN 2003: 215). El cuento Crimen libre nos explica la causa del asombro que suscitaba la novedad del skating ya que «no estaba por entonces tan extendida como ahora la costumbre de patinar, y no siempre había valientes que se prestasen a calzarse los patines y a describir curvas sobre la superficie lisa» (PARDO BAZÁN 1990, I: 455). Las Amézagas son, desde luego, en este ámbito, unas mujeres en la vanguardia ${ }^{29}$.

De origen inglés es asímismo el férrea determinación que demuestra Afra, la implacable protagonista del cuento del mismo nombre a quien se describe como «una voluntad. Puedo torcerme, pero no quebrantarme. Debajo del elegante maniquí femenino escondo el acerado resorte de un alma» (PARDO BAZÁN 1990, I: 307). Su educación estricta y esmerada se desarrolla en Inglaterra y Pardo Bazán destaca «el barniz de Inglaterra [...]: traía ciertos gustos de independencia y mucha afición a los ejercicios corporales. Cuando llegó la época de los baños no se habló en el pueblo sino de su destreza y vigor para nadar: una cosa sorprendente» (PARDO BAZÁN 1990, I: 307, 308). Y, como es lógico, para nadar, la intrépida Afra viste la ropa apropiada: un «traje marinero, de sarga azul oscura» (PARDO BAZÁN 1990, I: 309). Como Miss Annie, las nadadoras inglesas se ven con extrañeza en la pacata sociedad española ${ }^{30}$. De hecho, en el cuento Paria, en una conversación entre dos amigas que se están vistiendo para acudir al teatro, la menos atrevida, Margarita reprocha a la osada Piedad: «Ni una miss solterona te gana en excentricidad» (PARDO BAZÁN 1990, III: 83).

En El saludo de las brujas, (1899) Rosario también es una mujer de su tiempo. En la década en la que emerge la chica Gibson, la chilena practica deportes de todo tipo que se traslucen en su indumentaria. Durante su retiro en Ercolani ella y su enamorado disfrutan del mar: «Rosario era gran nadadora, Felipe algo menos, pero ella le amaestraba y sostenía» (PARDO BAZÁN 2000, IV: 239). También es una magnífica amazona y su indumentaria se ajusta en cada momento a las necesidades de su actividad física: «Rosario montaba sin miedo, y daba gusto verla derecha en la silla, con el magnífico rodete de su pelo recogido bajo el sombrerillo de fieltro a la tirolesa y el mórbido cuerpo modelado por el paño de su traje» (PARDO BAZÁN 2000, IV: 240).

Montar a caballo es una habilidad admirable en una mujer ya que implica el control de un animal que puede resultar peligroso. En Los pazos de Ulloa, entre la colección de reliquias de vestuario presentes en el desván de las primas de Moscoso, destaca la presencia de «Una lindísima chaqueta de grana, con las insignias de coronel bordadas en plata por bocamangas y cuello, herencia de la abuela de don Manuel Pardo, que según costumbre de su época, autorizada por el ejemplo de la reina María Luisa, usaba el uniforme de su marido para montar diestramente a horcajadas» (PARDO BAZÁN 1997: 206).

\footnotetext{
${ }^{29}$ En su libro de los pasajes, Walter Benjamin pone de manifiesto cómo en los años 80 del siglo XIX se produce la prefiguración inconsciente de lo que más tarde será la indumentaria deportiva, especialmente para la práctica del ciclismo y de la hípica, actividades en las que los atavíos poseían un gran potencial seductor. Citado en PAZ GAGO, J. M., El octavo Arte: La moda en la sociedad contemporánea, A Coruña, Hércules, ediciones, 2016: 84.

${ }^{30}$ Los baños de mar se recomendaban porque resultaban saludables para el organismo ya que regulaban la circulación y abrían el apetito. En El arte de ser bonita, ${ }^{\circ}$ 9, 1904: 174 se subrayaba la necesidad de conocer una serie de reglas para evitar cualquier complicación. PASALODOS SALGADO, Mercedes, Ibídem, p. 76.
} 
Sin embargo, Nucha, la futura mujer de don Pedro ya hace gala de su debilidad física y de su carácter remilgado y mojigato, en palabras de su marido, cuando demuestra sus nulas habilidades como amazona: «-¿Tienes miedo, chica? Tú no estarás acostumbrada a montar. ¿Has andado alguna vez en esta casta de aparejos? ¿Sabes tenerte en ellos? Nucha permanecía indecisa, recogiendo el vestido con la diestra, sin soltar de la otra el saquillo de viaje. Al cabo murmuró: - Lo que es tenerme, sé...» (PARDO BAZÁN 1997: 234).

Esta flaqueza de cuerpo y espíritu contrasta con la fortaleza de las mujeres de Castrodorna, como el ama de cría de los Moscoso, a las que Emilia Pardo Bazán describe, en la misma novela, como «una especie de amazonas, resto de las guerreras galaicas de que hablan los geógrafos latinos» (PARDO BAZÁN 1997: 282). De esta fuerza de la naturaleza ha mamado Manolita de quien Gabriel critica, en La madre naturaleza, que ha sido criada «como un marimacho, sin recato ninguno» (PARDO BAZÁN 1999: 229).

Mucho mejor esposa para el señor de Moscoso que Nucha, hubiera sido la «activa y resuelta Mayorazga de Bouzas», ágil jinete que se refresca con vino en las tabernas y que, en la feria de Monterroso, «que convoca a todos los "sportsmen" rurales, [...], monta con soltura una yegua muy cuca, de cuatro sobre la marca, vivaracha, torda, recastada de andaluza [...] Completaba el regalo rico albardón y bocado de plata; pero [la Mayorazga], dejándose de chiquitas, encajó a su montura un galápago (pues de sillas inglesas no hay noticia en Bouzas)» (PARDO BAZÁN 1990, II: 21).

La hípica dota a las mujeres que la practican de un aura especial. En el cuento Por la gloria la protagonista es una amazona ciega que luce para mayor comodidad una «cabellera rizosa y corta» (PARDO BAZÁN 1990, IV: 102) ${ }^{31}$. Sus habilidades destacan en la pista de un circo y para que nada distraiga al público de su pericia viste:

Su elegante torso, cautivo en la sencilla casaca de negro paño, masculinamente desdeñosa de todo adorno, jamás se había erguido tan airosamente sobre el diminuto sillín. Nunca su cabeza había parecido tan bella, con belleza de arcángel de miniatura, como en aquel momento espantoso. Nunca el magnífico caballo y la briosa mujer se habían identificado de tal suerte, al correr a la misma demencia (PARDO BAZÁN 1990, IV: 103, 104).

Este retrato majestuoso se repite en La Quimera en donde Silvio Lago manifiesta su admiración por la duquesa de Flandes quien entra en su estudio «a paso cadencioso y arrogante, sin crujidos sedosos reveladores de frufrús, arrastrando majestuosamente su faldamenta de paño oscuro, semejante, como todo lo que ella viste - a pesar de proceder del gran modisto-, a una falda de amazona» (PARDO BAZÁN 1991: 289, 290 ). La magnificencia del porte de la duquesa es atribuida por el pintor a «un género de belleza peculiar en su tipo viril, de grandiosas líneas, en su torso prolongado y sólido de cazadora y de regeneradora de raza» (PARDO BAZÁN 1991: 291). Estas observaciones de Lago son muy reveladoras de la especial consideración que tiene el hecho de que una mujer pueda asumir roles masculinos. Las vestimentas que las damas emplean para desempeñar actividades novedosas para ellas son un ejemplo de su capacidad de adaptación. Como se consideraba adecuado que una mujer

\footnotetext{
${ }^{31}$ MAGLI, Patrizia, Ibídem, pp. 52 y 53 reflexiona sobre el binomio pelo largo /corto.
} 
montase a horcajadas, las mujeres cabalgaban de lado postura con la cual resultaba considerablemente más difícil mantener el equilibrio ${ }^{32}$. Los trajes de amazona se construían sobre la base de unos pantalones cubiertos con una sobrefalda y, desde luego, resultaban también bastante incómodos y poco aptos para cabalgar con soltura ${ }^{33}$. El vestuario apropiado es fundamental para montar hasta el punto de que en el cuento Benito de Palermo, Eva, la inglesa coprotagonista salva la vida de un accidente porque renuncia a cabalgar debido a que «no le gustaba su traje de amazona» (PARDO BAZÁN 1990, II: 154). Por su parte, la duquesa de Flandes, sabedora de la admiración que sus habilidades hípicas suscitan, quiere ser retratada por Lago no como una cursi de salón sino como una sportwoman:

Hasta la rodilla, que la representase con una chaquetilla verde, su faja carmesí, su pavero de fieltro gris, su larga pica de acosar y derribar empuñada; el atavío con que se solazaban en la dehesa boyal, metiéndose intrépida entre las reses, en las tientas. Es este castizo deporte uno de los contados antojos tocados de extravagancia de mujer tan formal, y en él, cosa rara, coinciden sus aficiones y las de su marido, siempre entregado al sport (PARDO BAZÁN 1991: 292).

También en Dulce dueño, Lina Mascareñas reivindica, metafóricamente su condición de mujer fuerte, con aspiraciones más allá del matrimonio ${ }^{34}$ y que se vale por sí misma, recurriendo a la figura de la amazona: «Otra lucha, ardiente, nos llama. Otro sport, como ahora dicen... ¿Usted supone que la mujer no puede jugar a ese juego? Vaya si puede. Detrás de cada combatiente suele haber una amazona; detrás de cada poderoso, una reina social» (PARDO BAZÁN 1989: 225).

Lejos de ser una amenaza para el hombre, la mujer fuerte y valiente se configura, en estos relatos de Pardo Bazán, como un reto y su derrota por parte del varón puede ser muy satisfactoria para reforzar el orgullo y poder masculinos ${ }^{35}$.

\section{Amazonas viajeras}

La Quimera recoge los inicios de la afición femenina por el automovilismo ${ }^{36}$. Emilia Pardo Bazán describe por duplicado el vestuario de Clara Ayamonte para la práctica de esta actividad. Primero, la autora relata cómo Clara enseña a su pretendiente, Donado, el «traje de camino, de masculina forma, el amplio abrigo-saco color polvo, el sombrero de fieltro, donde gallardeaba un pichón con las alas extendidas» (PARDO BAZÁN 1991: 325). Más adelante se la describe «con traje

\footnotetext{
${ }^{32}$ La imagen de la mujer sobre el cuadrúpedo debía transmitir elegancia al montar con soltura. A la hora de subir o bajar del caballo también había que demostrar gracia y agilidad. Ese porte femenino se reforzaba con el paso elegido. Mientras que el trote podía traer graves consecuencias, si no se manejaban bien las riendas y las espuelas; el galope se distinguía por su sentido fascinador, mientras que el paso castellano contribuía a la elegancia de la amazona. En Madrid, los lugares elegidos por las amazonas fueron la Casa de Campo, el Retiro y Moncloa, los mismos espacios elegidos por las ciclistas y por las amantes del automovilismo. PASALODOS SALGADO, Mercedes, Ibídem, p. 75.

${ }^{33}$ FOGG, Marnie, Ibídem, p. 287.

${ }^{34}$ GUTIÉRREZ ALVAREZ, Ruth, Ibídem, p. 32

${ }^{35}$ EXPÓSITO GARCÍA, Mercedes, Ibídem, p. 70 señala que este papel retador fue adaptado por la Historia social a partir del modelo de las míticas amazonas de la Antigüedad.

${ }^{36} \mathrm{El}$ automovilismo a finales del siglo XIX se empezó a convertir en un divertimento fascinante. En un primer momento, las mujeres, prefirieron disfrutar de un cómodo viaje y no ponerse delante del volante. En principio, la conducción de una máquina que se alimentaba de gasolina, no entrañaba ninguna complicación higiénica La contraindicación más inmediata que indicaban las revistas higienistas del momento fue el peligro ante un exceso de velocidad. Ver PASALODOS SALGADO, Mercedes, Ibídem, pp. 76 y 77
} 
de auto, velo enorme y antiparras abultadas» (PARDO BAZÁN 1991: 328) ${ }^{37}$. En esta aventura, aparentemente alocada, acompañan a la Ayamonte dos mujeres, cómo no de nacionalidad inglesa, descritas por doña Emilia como «elegantes y excéntricas, curiosas, ilustradas y fútiles a la vez» (PARDO BAZÁN 1991: 323) Ambas son también amigas de la admirada duquesa de Flandes y una de ellas, lady Mortimer, es dueña de un automóvil. De nuevo, las mujeres inglesas son las joyas de la corona, las reinas de la fiesta y la vanguardia de las féminas.

Inglaterra es la cuna de las mujeres de acción, un prototipo femenino que viste austeros trajes de chaqueta de líneas rectas y masculinas y que desafían, con su actitud y su indumentaria, el orden establecido $^{38}$. La viajera británica que aparece en El engaño es un ejemplo de una de estas mujeres animosas, que «andaba al paso largo e igual de una mujer bien formada, que calza holgadamente y usa ropa corta» (PARDO BAZÁN 1990, III: 28). Sólo las féminas anglosajonas son capaces de recorrer mundo sin compañía. Sola viaja «la amiga inglesa, que había venido a vernos en el curso de un viaje de turismo» en el cuento Eterna Ley (PARDO BAZÁN 1990, III: 269). La desenvoltura de esta raza femenina especial, de una «originalidad excéntrica y picante», se ve acreditada de nuevo en Un viaje de novios cuando, la primera vez que Artegui ve a una Lucía solitaria en el tren, se hace la siguiente reflexión:

Acaso la viajera fuese una miss inglesa o norteamericana, provista de rodrigón y paje con llevar en el bolsillo un revólver de acero de seis tiros. Pero aunque era Lucía fresca y mujerona como una Niobe, tipo muy común entre las señoritas yankees, mostraba tan patente en ciertos pormenores el origen español, que hubo de decirse a sí mismo el que la consideraba: «no tiene pizca de traza de extranjera (PARDO BAZÁN 2003: 103).

Las mujeres anglosajonas representan el ideal de la mujer independiente. No en vano la lucha sufragista enfocada a la conquista de derechos laborales, políticos y sociales, está en pleno apogeo en los años en que Pardo Bazán escribe sus obras. Doña Emilia, un prodigio de erudición en todos los ámbitos, conoce bien el tema y tiene una opinión formada al respecto ${ }^{39}$. Miss Annie, como ya hemos visto, es el modelo prototípico de la nueva mujer emancipada pero los cuentos de Pardo Bazán recogen otros ejemplos significativos. Otro caso de esta independencia insobornable la encontramos en el cuento Por España en donde la protagonista, una viajera inglesa recién casada, es descrita de manera muy reveladora:

La ex señorita Gladys Stilton, doctora en Leyes, acuarelista de afición y gran jugadora de tenis, llevaba con gentil desembarazo su sombrero de fieltro gris que cimeraba una gaviota enorme, y se envolvía airosamente en la larga manta de viaje, de cuadros amarillos y marrón. A pesar de las fatigas de la iniciación amorosa, su cutis parecía de rosa muy fresca, como parecía de seda lasa fina su cabello, recogido en moño griego, saliente y firme. Si mistress Gladys tenía las ideas largas, no podía decirse que tuviese el pelo corto. Sus ojos azul marino, cándidos, expresaban a veces una especie de infantil asombro; pero sus manos eran fuertes y huesudas cual las de un muchacho, y sus esbeltas y robustas formas denotaban el cultivo de la

\footnotetext{
${ }^{37}$ La revista Blanco y negro, 1905 n ${ }^{\circ}$ 716, recomendaba su uso diciendo: El velo, por muy tupido que sea, nunca resguarda los ojos como unas buenas antiparras de cristal, con su anteojera de caucho o de seda. PASALODOS SALGADO, Mercedes, Ibídem, p. 77.

${ }^{38}$ WOOLF, Virginia, Les années, París, Gallimard, 2007: 234. Uno de los arquetipos más claros de esta mujer de acción fue creado por Virginia Woolf a través del personaje de Rose en Los años.

${ }^{39}$ PAREDES NÚÑEZ, Juan, Ibídem, p. 308. Véase también MAYORAL, Marina, Ibídem, pp. 101-132.
} 
energía física y la excelente asimilación de las amplias lonjas de buey asado (PARDO BAZÁN 1990, III: 60, $61)$.

En este caso, los datos que destaca la novelista acerca de este personaje son su formación, doctora en Leyes, y su afición al dibujo. En el relato Vengadora también la yanki protagonista, de marcado tipo extranjero y evidente desaliño indumentario revelado en su raído saquillo, porta un cuaderno de bocetos y ejerce una profesión poco convencional e impensable en una mujer española: «soy «tipógrafo». Trabajo..., es decir, trabajaba, en una imprenta de Boston. Ahora no sé qué haré» (PARDO BAZÁN 1990, II: 261, 262). En La oración de Semana Santa reaparece de nuevo el prototipo ejemplar de fémina anglosajona, en este caso Miss Ada Sharpton descrita como una «de esas mujeres intrépidas e infatigables que registran con emoción y curiosidad los más apartados confines del planeta» (PARDO BAZÁN 1990, II: 255) .

Todas estas mujeres decididas son admirables y Pardo Bazán ha querido refrendar con su ejemplo el ideal femenino al que debe aspirar toda mujer, también en España ${ }^{40}$.

\section{No hay rosas sin Espina: la femme fatal}

El colmo del desafío, la quintaesencia de "la nueva Eva" es Espina Porcel. Esta mujer cosmopolita, nómada y desafiante adopta los modos y maneras de los dandies más recalcitrantes. Su hastío, su vestimenta provocativa, su exacerbado esteticismo y su falta de delicadeza al expresar sus emociones la convierten en objeto de total admiración. El inconformismo de este personaje rinde a todos los que la rodean y la convierten en la reina indiscutible de cualquier evento, ya sea en el "garbanzal" madrileño o en los salones refinados de París.

La protagonista de La Quimera entra ya en una nueva categoría de mujer. El propio Lago la describe en los siguientes términos: «Desde que he visto a Espina, se me descubre la mujer moderna, la Eva inspiradora de infinitas direcciones artísticas, agudamente contemporáneas» (PARDO BAZÁN 1991: 337). La Porcel es una femme fatal, una nueva Lilith más que una nueva Eva, una devoradora de hombres que está casada pero flirtea con Silvio aunque ello suponga desairar a su amante, Valdivia.

Sus ropas la convierten, según Silvio en una «criatura infernal», una «vampira» que «arrolla los tentáculos al cuerpo» (PARDO BAZÁN 1991: 448) ${ }^{41}$. La imagen de Espina como una chupasangres con los labios ensangrentados se reproduce de nuevo cuando Lago subraya: «aunque observaba los labios de Espina, no veía en ellos huella de sangre, sino la del carmín fino que los pintaba» (PARDO BAZÁN 1991: 396 ${ }^{42}$. Espina, haciendo honor a su nombre, enreda a los hombres en sus trampas y los desvía de sus verdaderos intereses del mismo modo que enrosca, ciñe y pliega las telas en torno a su cuerpo. Muy ilustrativa de esta idea vampirizadora es la imagen del maléfico personaje ejerciendo,

\footnotetext{
${ }^{40}$ MAYORAL, Marina, Ibídem, p. 107 y PAREDES NÚÑEZ, Juan. Ibídem, p. 306.

${ }^{41}$ Esta actitud "monstruosa" de Espina ha sido reseñada como un símbolo del decadentismo modernista en LATORRE CERESUELA, Yolanda, "Decadentes y diletantes, la mujer en la última Pardo Bazán”, Lectora, heroína, autora (la mujer en la literatura española del siglo XIX). III Coloquio (Barcelona 23-25 octubre de 2002), 2005:198.

${ }^{42}$ MAGLI, Patrizia, Ibídem, p. 76 señala que la boca es el sujeto activo de la voluntad alimenticia y, a su vez, es el objeto pasivo de todos los deseos antropofágicos (morder, lamer, succionar, chupar...).
} 
con su aliento, una especie de posesión maligna sobre el pintor en esta escena ${ }^{43}$ : «Su respiración se espació sobre mis mejillas, con revuelo sutil de mariposa, y su brazo derecho desquició violentamente mi cabeza, inclinándola hacia sí, mientras la mano perlina me revolvía los mechones del pelo y me arañaba con las sortijas la frente» (PARDO BAZÁN 1991: 365).

Efectivamente, Espina cautiva a Silvio, se lo lleva a París y cuando él parece querer volar solo, intenta humillarlo. Espina es comparable a las mujeres más manipuladoras de la Antigüedad. Silvio la equipara con Cleopatra porque, además, comparten la misma refinada y vana superficialidad ${ }^{44}$ : «Para Espina no existe eso, ni nada, fuera de lo bonito y lo selecto, de ese aquilatamiento sensual de la exterioridad, que hace de ella una especie de Cleopatra -pues, como le sucedía a la reina de Egipto, su vida es inimitable» (PARDO BAZÁN 1991: 358).

En Espina, como pasaba con la no tan bella Cleopatra, todo es falso. Lago lo expresa claramente cuando menciona que encuentra en «su estilo ultramodernista y decadente, elementos de la mentira estética de otras edades» (PARDO BAZÁN 1991: 333).

Todo en la Porcel son artimañas para salirse con la suya guardando las apariencias. Ella misma, en una fantasmagórica aparición, se revela a Silvio como una gran mentira. «Mi pelo es tintura, mi húmeda boca es pintura, mi atractivo no es la exhibición de mi cuerpo, sino el saber recatarlo, cual se recata los misterios de los santuarios» (PARDO BAZÁN 1991: 355) ${ }^{45}$. El egoísmo de Espina hace de ella un ángel caído que tiene en su propio cuerpo su ídolo. La adoración por sí misma la lleva a no reparar en ningún tipo de gasto para su autocomplacencia: «Saca de su escarcela de piel ceniza, toda cuajada de capitolinos de rubí caro y diamantes menudos, una petaca y una fosforera de oro verde, decoradas con lirios de esmalte, primoroso modelo acuático. Pido las joyas para admirarlas y apreciar de cerca el lujo intensivo y exasperado de la cosmopolita» (PARDO BAZÁN 1991: 337).

Además de fashionista Espina es, como acabamos de ver, fumadora e, incluso en sus vicios encontramos detalles de su refinamiento: «Hasta los cigarros son especiales; según me dice, se los fabrican en Egipto expresamente. Enciende uno y me lo presenta. Fumamos, risueños, libres por un instante del trabajo y de la pose» (PARDO BAZÁN 1991: 337) ${ }^{46}$.

Espina fuma con el mismo descaro y desenfado con el que viste: «Arrastra un traje de gasa, de incierto matiz, de esos matices afeminados que la moda ha bautizado con el nombre de "colores pastel, es lo más atrevido que he visto nunca» (PARDO BAZÁN 1991: 354).

\footnotetext{
${ }^{43}$ Ibídem, p. 75 subraya que la boca es nuestra parte más íntima: «Es el acceso directo hacia el interior y del interior hacia el exterior. El término romano fauces en plural indicaba la boca y la garganta pero también el abismo en cuanto entrada estrecha a un lugar más amplio: el cuerpo interno, visceral».

${ }^{44}$ D’AUREVILLY, Barbey, Del dandismo y de George Brummell., Barcelona, Anagrama, 1974: 131 y 132. D’Aurevilly define la vanidad como búsqueda inquieta de la aprobación de los demás e inextinguible sed del aplauso de la galería. Cuando la vanidad está satisfecha se habla de fatuidad.

${ }^{45}$ MAGLI, Patrizia, Ibídem, pp. 51,76 y 87 se ocupa de estos temas. El maquillaje viste y repara a la mujer. La boca femenina desnuda es vulnerable. Porcel viste su boca para dotarla de fuerza y viste también su rostro ya que repudia la desnudez. También tiñe su pelo gris, archivo del pasado en palabras de Allan Poe, para evitar que denuncie despiadadamente cuánto tiempo ha pasado.

${ }^{46}$ Pardo Bazán también era una fumadora empedernida de cigarettes orientales un vicio repudiado por Juan Montalvo, poeta ecuatoriano que fue uno de los amigos galantes de la condesa. BURDIEL BUENO, Isabel, Ibídem, p. 287.
} 
La Porcel, a la última incluso en lo tocante a vicios, fuma tabaco y también opio y, naturalmente, los primores de su vestimenta se reflejan también en sus accesorios de drogadicta: «Con calma e indiferencia en, que había menosprecio, sacó un cigarro de su primorosa petaca y lo encendió, demostrando, como casi siempre que fuma, impresión de bienestar, de euforia, debida, sin duda, al opio que encierran sus papelitos largamente emboquillados» (PARDO BAZÁN 1991: 375).

Su actitud aquí como en todo es seductora y su ánimo provocador:

Cuando la dije que, por indicación de Valdivia, les acompañaría a París, me miró atentamente, y en sus ojos de venturina derretida, irradiaciones, vi lucir una chispa sardónica, cruel. Hizo luego un gesto de los que se hacen cuando el destino se impone.

-Mucho me alegro de que le tengamos a usted por allá — pronunció despacio, con expresión enigmática (PARDO BAZÁN 1991: 376).

Espina, como acabamos de ver, se maquilla y mucho, para acentuar su sensualidad:

¡Su cara, su cuerpo, pchs! Sus ojos avellana, en que parecen hormiguear puntilleos de oro, ni son grandes ni dulces. Su nariz respinga, delatando algún plebeyo atavismo. Su boca ya sonríe juguetona, ya señala un pliegue de tedio desdeñoso. Su pelo de luz no lo debe a la naturaleza, sino al peluquero, a botecitos de aguas y mudas. Afeite debe de ser también lo que presta a sus mejillas, hundidas imperceptiblemente, ese toque tan puro, esa idealidad de lo florido sobre lo nacarado, y a sus labios pequeños, carnosos, sinuosos y húmedos, ese tono de coral marino entre agua amarga, demasiado vivo, insolente (PARDO BAZÁN 1991: 336).

El maquillaje es, en ella, un arte y una manera de aparentar lo que no es. En su caso, los artficios de tocador pretenden simular una salud de la que carece. Sus labios color carmín y su indolencia revelan, además, su egoísmo y un afán de destacarse y sobresalir de entre las demás mujeres ${ }^{47}$. Si en otras lo admirable es la virtud, en Espina, lo admirable es su descaro y desenvoltura para el vicio. ${ }^{48}$

Su poder de seducción es asombroso. El propio Lago confiesa: «Sin embargo me deleito en la amoralidad de Espina, como si deshiciese en la boca un fondán muy delicado, sápido a quintaesencias, de gusto desconocido, de perfume que trastorna» (PARDO BAZÁN 1991: 359).

A pesar de sus costumbres más que discutibles, Espina demuestra en su decadente militancia una rebeldía valiente propia de un $d a n d y$. Su dandismo se basa en su independencia, en la vulneración de las normas y en su temeridad. Pero la osadía de Espina es ejercitada con tacto, encontrando un punto intermedio entre la originalidad y la excentricidad ${ }^{49}$. La Porcel es una rara avis porque ha asumido todos los vicios de los hombres con todas sus consecuencias pero cuenta con la indulgencia social. Es un monstruo, consciente de su anormalidad, pero nadie la censura. Espina es un Nosferatu que sigue implacablemente su camino hacia la autodestrucción y arrastra con ella a quien se encuentra. Virginia Woolf destacaba: «es letal ser lisa y llanamente un hombre o una mujer; hay que ser un hombre

\footnotetext{
${ }^{47}$ MAGLI, Patrizia, Ibídem, pp. 88-91.

${ }^{48}$ Ibídem, p. 50. Platón en la República (IV, 445c) decía que «único es el aspecto de la virtud pero infinitos son los del vicio». El vicio es expresivo tiene carácter, es menos uniforme y repetitivo, menos predecible y menos aburrido, y en definitiva, más diferenciador.

${ }^{49}$ D'AUREVILLY, Ibídem, p. 154.
} 
femenino o una mujer masculina» ${ }^{50}$. Dentro de su corsé y sin renunciar a su femineidad exterior, Espina exhibe una libertad de acción propia del dandy, el arquetipo masculino más transgresor.

\section{Bibliografía}

BURDIEL BUENO, Isabel, Emilia Pardo Bazán, Madrid, Taurus, 2019.

CORONA VERDÚ, Rafael, "La emancipación femenina a través del denuedo velocípedo", Femeris, vol. 2, no 2, 2017.

D’AUREVILLY, Barbey, Del dandismo y de George Brummell., Barcelona, Anagrama, 1974.

DE BURGOS SEGUÍ, Carmen, El arte de ser mujer, Pedro Gómez Carrizo, editor, España, Biblok editores, 2018.

DE GABRIEL, Narciso, "Emilia Pardo Bazán, las mujeres y la educación. El Congreso pedagógico (1892) y la cátedra de Literatura (1916)", Historia y memoria de la educación, nº 8, 2018.

DÍAZ MARCOS, Ana María, La edad de seda. Representaciones de la moda en la literatura española (1728-1926), Universidad de Cádiz, Cádiz, 2006.

DÍAZ PADRÓN, Matías, "Religión y devoción de Van Dyck en el coleccionismo español del siglo XVII", Anales de Historia del Arte, nº 20, 2010.

DORCA, Toni, "Tres heroínas ante el matrimonio, Marisalada, Tristana y Feíta”, Lectora, heroína, autora: (la mujer en la literatura española del siglo XIX). III Coloquio (Barcelona 23-25 octubre 2002), 2005.

EXPÓSITO GARCÍA, Mercedes, De la garçonne a la pin-up. Mujeres y hombres en el siglo XX, Madrid, Cátedra, 2016.

FUKAI, A., SUOH, T., IWAGAMI, M., KOGA, R., Y NII, R., MODA: Una historia desde el siglo XVIII al siglo XX. La colección del Instituto de la indumentaria de Kyoto, China, Taschen, Bibliotheca Universalis, 2006.

FOGG, Marnie, Moda, toda la Historia, Barcelona, Blume, 2014.

GUTIERREZ ALVAREZ, Ruth, "La batalla ideológica entre la carne y el espíritu. Una aproximación a los personajes femeninos de las últimas novelas de Emilia Pardo Bazán”, La tribuna. Cadernos de estudos da Casa Museo Emilia Pardo Bazán, n 12, 2017.

HERRERO DE VIDAL, Melchora, Para las mujeres, reflexiones y consejos, Madrid, Imprenta de los hijos de M.G.Hernández, 1905.

LATORRE CERESUELA, Yolanda, "Decadentes y diletantes, la mujer en la última Pardo Bazán”, Lectora, heroína, autora (la mujer en la literatura española del siglo XIX). III Coloquio (Barcelona 23-25 octubre de 2002), 2005.

MAGLI, Patrizia, Pitturare il volto. Il Trucco, l’Arte, la Moda, Venezia, Marsilio Editori, 2013.

MAYORAL, Marina, “Tristana y Feíta Neira, dos versiones de la mujer independiente”, Galdós, centenario de Fortunata y Jacinta, J. Arellano (ed.) UCM, 1989.

${ }^{50}$ WOOLF, Virginia, Ibídem, 2012: 138. 
MAYORAL, Marina, "Emilia Pardo Bazán ante la condición femenina”, Estudios sobre la obra de Emilia Pardo Bazán. Actas de las jornadas conmemorativas de los 150 años de su nacimiento, A Coruña, Fundación Pedro Barrié de la Maza, 2003.

PAREDES NÚÑEZ, Juan, “El feminismo de Emilia Pardo Bazán”, Cuadernos de estudios gallegos, Tomo XL, fascículo 105. CSIC, 1992.

PARDO BAZÁN, Emilia, Cuentos completos, tomo I, Edición de Juan Paredes Núñez, Fundación Barrié de la Maza, La Coruña, Galicia editorial S.A., GAESA, 1990.

PARDO BAZÁN, Emilia, Cuentos completos, tomo II, Edición de Juan Paredes Núñez, Fundación Barrié de la Maza, La Coruña, Galicia editorial S.A., GAESA, 1990.

PARDO BAZÁN, Emilia, Cuentos completos, tomo III, Edición de Juan Paredes Núñez, Fundación Barrié de la Maza, La Coruña, Galicia editorial S.A., GAESA, 1990.

PARDO BAZÁN, Emilia, Cuentos completos, tomo IV, Edición de Juan Paredes Núñez, Fundación Barrié de la Maza, La Coruña, Galicia editorial S.A., GAESA, 1990.

PARDO BAZÁN, Emilia, El encaje roto. Antología de cuentos de violencia contra las mujeres. Edición de Cristina Patiño Eirín, Zaragoza, Contraseña, 2018.

PARDO BAZÁN, Emilia, La prueba, Obras completas, tomo III, Domingo Ynduráin, director, Madrid, Biblioteca Castro, RAG, 1999.

PARDO BAZÁN, Emilia, Un viaje de novios, Obras completas, tomo I, Domingo Ynduráin, director, Madrid Biblioteca Castro, RAG, 1999.

PARDO BAZÁN, Emilia, El cisne de Vilamorta, Obras completas, tomo I, Domingo Ynduráin, director, Madrid Biblioteca Castro, RAG, 1999.

PARDO BAZÁN, Emilia, Doña Milagros, Obras completas, tomo III, Domingo Ynduráin, director, Madrid, Biblioteca Castro, RAG, 1999.

PARDO BAZÁN, Emilia, Memorias de un solterón, Obras completas, tomo III, Domingo Ynduráin, director, Madrid, Biblioteca Castro, RAG, 1999.

PARDO BAZÁN, Emilia, El saludo de las brujas, Obras completas, tomo IV, Domingo Ynduráin, director, Madrid, Biblioteca Castro, RAG, 2000.

PARDO BAZÁN, Emilia, La sirena negra, Obras completas, tomo V, (pp. 401-543), Madrid, Biblioteca Castro, RAG, 2000.

PARDO BAZÁN, Emilia, Dulce dueño, Marina Mayoral, edición, Madrid, Editorial Castalia, SA, 1989.

PARDO BAZÁN, Emilia, La Quimera, Marina Mayoral, edición, Madrid, Cátedra, Letras hispánicas, 1991.

PARDO BAZÁN, Emilia, Los pazos de Ulloa, Ma Ángeles Ayala edición, Madrid, Cátedra, 1997. PARDO BAZÁN, Emilia, La madre naturaleza, Ignacio P. López edición, Madrid, Cátedra, 1999. PARDO BAZÁN, Emilia, Un viaje de novios, Marisa Sotelo Vázquez edición, Madrid, Alianza, 2003. PARDO BAZÁN, Emilia, Viajes por Europa, Por Francia y por Alemania, Madrid, Bercimuel, 2004. 
PASALODOS SALGADO, Mercedes, El traje como reflejo de lo femenino. Evolución y significado, Madrid 1898-1915, Madrid, UCM, 2000.

PAZ GAGO, J. M., El octavo Arte: La moda en la sociedad contemporánea, A Coruña, Hércules, ediciones, 2016.

POZO GARCÍA, Alba, “Quiero ser santa: misticismo y decadencia en Dulce dueño de Emilia Pardo Bazán”, La tinta en la clepsidra. Fuentes, historia y tradición en la literatura hispánica, Barcelona, Boadas, Chávez y García Vicens (eds), 2012.

TABOADA NOYA, Ruth, La violencia en los cuentos de Emilia Pardo Bazán, Santiago de Compostela, Facultad de Filología, USC, 2016.

WOOLF, Virginia, Les années, París, Gallimard, 2007.

WOOLF, Virginia. Una habitación propia, Madrid, Alianza, 2012.

\section{Abreviaturas}

RAG: Real Academia Galega.

MO: manuscrito original.

C: carta. 